\title{
東日本大震災において被害を受けた杭基礎の耐震性の評価 EVALUATION OF SEISMIC PERFORMANCE OF PILE FOUNDATIONS DAMAGED DURING THE 2011 GREAT EAST JAPAN EARTHQUAKE
}

\author{
金子 治*, 中井正一** \\ Osamu KANEKO and Shoichi NAKAI
}

\begin{abstract}
There were several cases reported where buildings had to stop functioning normally because of the damage to foundations during the 2011 Great East Japan earthquake. The authors carried out static analyses using a foundation structure model in order to investigate the cause of damage to pile foundations by focusing on three typical buildings. Lateral load at pile head and differential movement of soils were estimated based on a seismic response analysis by using recorded ground motions of the 2011 Great East Japan earthquake and by looking into the soil profiles and structural characteristics of buildings. Load-deformation characteristics of pile elements and soil springs were formulated so that the model can incorporate nonlinear behaviors. Results obtained from the analysis explain fairly well the actual damage of pile foundations. It was confirmed that a controlling factor causing damage to pile foundations is the existence of soft soils and the variation of surface soil layers. The proposed procedure can be considered as a practical seismic design method of foundations that ensures a required performance for large earthquakes.
\end{abstract}

Keywords : Pile foundation, 2011 Great East Japan earthquake, Earthquake damage, Seismic design, Differential movement of soils, Soil spring 杭基礎，東日本大震災，地震被害，而震設計，地盤変形，地盤ばね

\section{1. はじめに}

東日本大震災 (2011 年東北地方太平洋沖地震) でも，1978 年宮城 県沖地震 ${ }^{1)}$ や 1995 年兵庫県南部地震 ${ }^{2), 3)}$ と同様に, 上部構造物は無 被害もしくは軽微な被害であっても杭基礎に被害を受けて建物が傾 斜して継続使用が困難となった事例が報告されている ${ }^{4), 5)}$.

大地震時の基礎構造の耐震性の評価については，超高層建築や免 震建物などでは上部構造の設計と合わせて行われることもあるが， その手法は設計者の判断に委衫られている。過去に地震のおいて生 じた基礎構造の被害のメカニズムについて検証された例 6),7,8)でも， 外力の評価方法や応力解析方法はそれぞれ異なっている。

一方, 現行の一般的な基礎構造の設計では,「過去の国内の地震で は，地下部分の破壊により建築物が崩壊に至った例は報告されてい ないこと等の理由により ${ }^{9} 」$, 法的には中小地震動に対する検討のみ が規定されている，そのため，耐震設計が行われていない年代の建 物だけでなく，現在設計・建設されている建物であっても，大地震 時に建物の機能維持に影響する被害が生じる可能性がある.

これまでにも安全限界時までの基礎構造の耐震設計の考え方 ${ }^{10)}$ が 示されてきており, 最近では耐震診断手法の提案 11)もなされている が，普及には至っていない。設計手法として確立されるためには， 実際の被害との対応をはかると同時に, 設計者の判断に左右されず,
同等の安全性が確保できるような一般性・実用性が必要であると考 えられる。

そこで，2011 年東日本大震災で実際に杭基礎が破損し，被害調查 （杭頭掘出し調査・インティグリティ試験）が行われ，かつ設計図 書が入手できている 3 つ建物を対象として，大地震時の基礎構造 の耐震設計手法として有効と考えられる外力の設定方法や解析モデ ルを用いて基礎構造の被害メカニズムについて検証するとともに， 被害との比較を通じて，これらの手法の適用性について検討した．

\section{2. 対象建物之被害状況}

今回の検討対象とした建物の諸元を表 1 に，東日本大震災におけ る被害状況を図 1 に示寸が，建物 A,Cでは長辺方向 $1 / 3$ 程度が部分 的に，建物 B では全体的（長辺方向が大きい）に傾斜した。傾斜部 分では杭の破損が確認されているが，上部構造は不同沈下に伴う被 害のみであり，いずれの建物も杭の補修および建物のジャッキアッ プの上，継続使用される予定である。被害調查で確認した杭の被害 状況を表 2 に示す，表中で「地中部で破損の可能性あり」は，杭の 非破壞試験（インティグリティ試験）により断面の不連続と考えら れる反射波が認められた深さを示しており，その深さで杭体の応力 はひび割れ〜曲げ降伏程度以上となっていたと推定される。 
なお，建物 $\mathrm{A}, \mathrm{B}$ は建設年代が古く杭の耐震設計は行われていない と推定されるが，建物 $\mathrm{C}$ は杭の耐震設計（短期許容応力度設計）が 行われていることを確認している.

表 1 検討対象建物の諸元

\begin{tabular}{|c|c|c|c|}
\hline & $\mathrm{A}$ & $\mathrm{B}$ & $\mathrm{C}$ \\
\hline 所在地 & 千葉県 & 福島県 & 福島県 \\
\hline 地形 & 低地 (谷部) & 低地 (谷部) & 台地之低地の境界 \\
\hline 建設年 & 1973 年 & 1985 年 & 1993 年 \\
\hline 構造規模 & $\begin{array}{l}\text { 地上 } 5 \text { 階地下なし } \\
\text { 壁式プレキャス上 }\end{array}$ & $\begin{array}{l}\text { 地上 } 4 \text { 階地下なし } \\
\text { 而震壁付ラーメン }\end{array}$ & $\begin{array}{l}\text { 地上 } 3 \text { 階地下なし } \\
\text { 耐震壁付ラーメ之 }\end{array}$ \\
\hline 沉の諸元 & PC 杭 $\phi 300$ & $\mathrm{PC}$ 杭 $\phi 350$ & PHC 杭(B 種) $\phi 400$ \\
\hline
\end{tabular}

表 2 杭の被害状況

\begin{tabular}{c|l|l}
\hline $\mathrm{A}$ & \multicolumn{1}{|c|}{$\mathrm{B}$} & \multicolumn{1}{|c}{$\mathrm{C}$} \\
\hline 傾斜部分で杭頭破損 & 建物全体で杭頭破損 & 傾斜部分の杭頭は全 \\
と地中部-4〜 7m 程 & かつ地中-3 - 4m 程 & 数破損かつ地中-2 \\
度で破損の可能性が & 度より下の数か所で & 6m 程度で破損の可 \\
あり, が混在 (図 5) & 破損の可能性あり & 能性あり \\
\hline
\end{tabular}

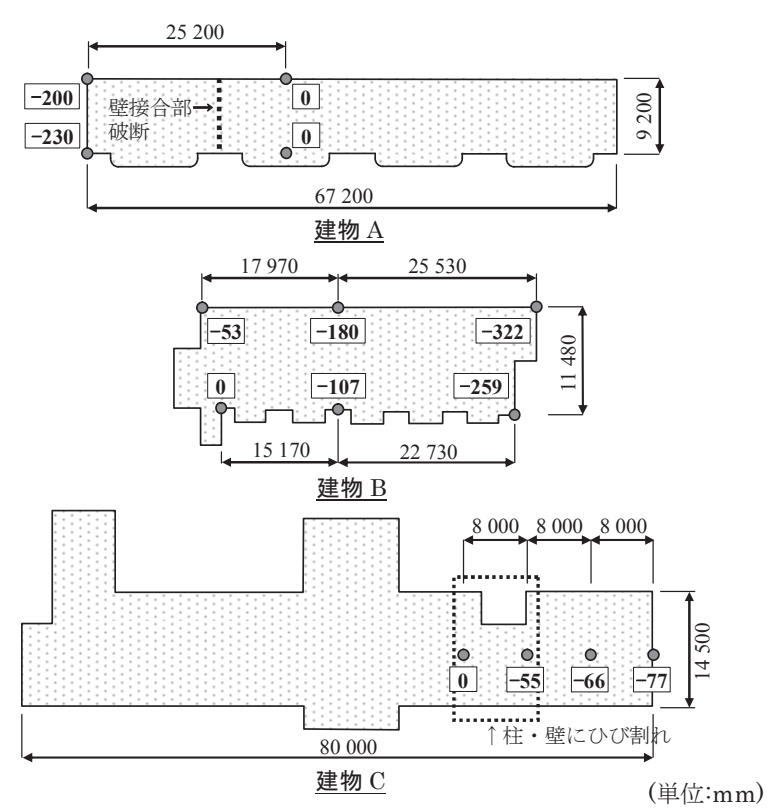

図 1 建物の被害状況（ $\square$ 上部構造の不同沈下量 $(\mathrm{mm})$ )

\section{3. 検討方法}

被害要因の検討にあたっては，外力・荷重および非線形の適切な 評価に加え, 今後の設計手法としての適用性も考慮して, 図 2 およ び以下に示す方法を採用した。

-地盤変形は, 入力地震動として近隣の観測記録から工学的基盤に おけるはぎ取り波を作成し, 敷地地盤の地盤調查結果から設定し た地盤モデルを用いた非線形時刻歴応答解析により算定した。地 盤の初期剛性を計算するためのせん断波速度 $V_{s}$ は, 標準貫入試験 の $N$ 值 1213)および近隣の地震観測点のデータを参考に設定した. 地盤の非線形性は修正 R-O モデルを用い, モデルの定数は安田ら の提案 ${ }^{14)}$ に基づく経験式に基づく $G-\gamma, h-\gamma$ 関係から設定した.

・杭頭水平力（慣性力）は，上部構造物を多質点モデルとし，上記 応答解析により得られた地表面応答加速度を用いた応答解析によ り算定した最大応答值とした。建物重量は設計図面に基づいて計 算し，各階の剛性については，上部構造は震動による被害はほと

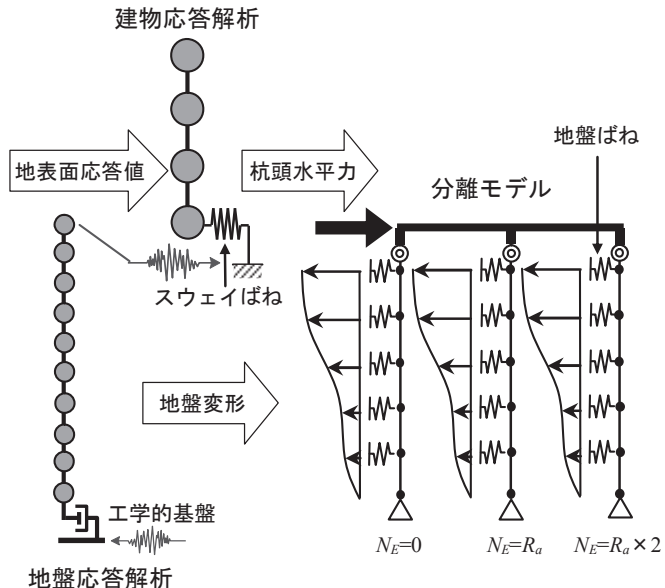

図 2 検討方法の概要

表 3 杭頭水平力 (()は杭 1 本あたり)

\begin{tabular}{|c|c|c|c|c|c|c|}
\hline 建物 & $\begin{array}{c}\text { 総重量 } \\
(\mathrm{kN})\end{array}$ & $\begin{array}{l}\text { 杭 } \\
\text { 本数 }\end{array}$ & $\begin{array}{c}\text { 総水平力 } \\
(\mathrm{kN})\end{array}$ & $\begin{array}{c}\text { 観㵋波最大值: } \\
\left(\mathrm{m} / \mathrm{s}^{2}\right)\end{array}$ & $\begin{array}{l}\text { 計測 } \\
\text { 震度 }\end{array}$ & $\begin{array}{c}C_{B}=0.2 \text { の時の } \\
\text { 総水平力 }(\mathrm{kN})\end{array}$ \\
\hline A & 35,654 & 138 & $9,763(70.7)$ & 2.33 & 5.0 & $6,790(49.2)$ \\
\hline B & 33,695 & 97 & $13,665(140.9)$ & 4.51 & 5.8 & $5,361(55.3)$ \\
\hline $\mathrm{C}$ & 65,292 & 153 & $28,542(186.5)$ & 6.19 & 5.8 & $11,807(77.2)$ \\
\hline
\end{tabular}

んど見られないことから， $A_{i}$ 分布に比例するものとして弾性固有 周期と合うよう設定した。また，地盤が軟弱な建物 $\mathrm{A}, \mathrm{B}$ では相互 作用ばねとして後述の式(2)から評価したスウェイばねを考慮す る。また，根入れ深さは浅く，その影響は無視している．表 3 に 算定した杭頭水平力の一覧を, 観測波最大值および標準層せん断 力 $C_{B}=0.2$ (短期許容応力度設計用) の水平力とあわせて示す. ・応力解析は, 代表構面について基礎ばり下のみを取り出して杭体 は線材，地盤はばねとした分離モデルによる静的増分解析とし， 杭頭水平力と地盤変形を同時に与えた，杭体の分割ピッチは，既 往の研究 ${ }^{15)}$ では杭径の 2 倍程度までは解に大きく影響しないこと が杭体が弾性体の場合に確認されている，杭体の非線形を考慮し た本研究では，杭径の $1 / 2$ 程度としてもほぼ同じ結果が得られる ことを確認した上で， $500 \mathrm{~mm}$ で統一した。

・地震時負担軸力 $N_{E}$ については, 本来は上部構造の解析を実施して 算定する必要があるが，本検討では，対象建物は低層であり，長 期支持力 $R_{a}$ に対し $N_{E}=0 \sim 2 \times R_{a}$ の範囲内で軸力の影響の上限と下 限を考慮できると判断し， $N_{E}=0, R_{a}, 2 \times R_{a}$ となる杭が各 $1 / 3$ ずつ あると仮定して 3 本 1 組での解析を実施した.

・地盤ば釉は，式(1)の間瀬・中井の提案モデル ${ }^{15)}$ を用いて非線形 性を考慮した曲線から設定した多折れ線モデルを用いた。

式(1)中の初期剛性 $K_{0}$ は式(2)により， $K_{0}$ の計算に用いる地盤の 変形係数および塑性地盤反力 $P_{\text {max }}{ }^{16}$ は, 地盤の応答解析と同様に $N$ 值から経験式を用いて設定し, 非線形化の度合いを表す定数 $u$ は深さ（上載圧）に応じて設定した.

$$
\begin{aligned}
& \frac{P(R)}{\delta(R)}=\frac{K_{0}}{1+\frac{K_{0}}{P_{\max } R} \frac{\left(1-R_{e}\right)}{u} \frac{2}{\pi} \ln \left\{\sec \left(\frac{\left\langle R-R_{e}\right\rangle}{1-R_{e}} \frac{\pi}{2}\right)\right\}} \\
& K_{0}=1.3 \frac{E_{s}}{\left(1-v^{2}\right)}\left(\frac{E_{s} B^{4}}{E I}\right)^{1 / 12}
\end{aligned}
$$


記号 $P, \delta$ : 地盤反力, 水平変位

$K_{0} \quad$ : 初期剛性

$P_{\max } \quad$ :極限地盤反力

$R \quad$ :正規降伏比 $=P(R) / P_{\max }$,

$\langle R\rangle \quad: R \geqq 0$ のとき $R, R<0$ のとき 0

$R_{e} \quad$ :弾性限の $R$ 值(ここでは 0 )

$u \quad$ :極限地盤反力に近づく度合いを表す定数

$E_{s}, v: V_{s}$ 值から計算した地盤の変形係数, ポアソン比

$B \quad$ : 杭直径

$E I \quad$ :杭の曲げ剛性

・杭体は，断面を構成する材料の応力ーひずみ関係を用いて平面保 持の仮定で計算した $M-\phi$ 関係から, 図 3 のトリーリニアモデルと した.ただし, 建物 $\mathrm{A}, \mathrm{B}$ の $\mathrm{PC}$ 杭は種別等が特定できないため $\mathrm{PHC}$ 杭 $\mathrm{A}$ 種の諸元を用いた。図中の 3 つの点はひび割れモーメント $M_{c}$, 降伏モーメント $M_{y}$, 破壞モーメント $M_{u}$ を示し, 解析上は破 壊モーメント $M_{u}$ 以降は $M_{u}$ を保持寸るモデルとなっており, 破壊 モーメント後の挙動は実際の現象と異なる可能性がある.

\section{4. 建物 $A$ の検討}

建物 $\mathrm{A}$ の杭伏図を図 4 に示す, 上部構造は地上 5 階地下なしの
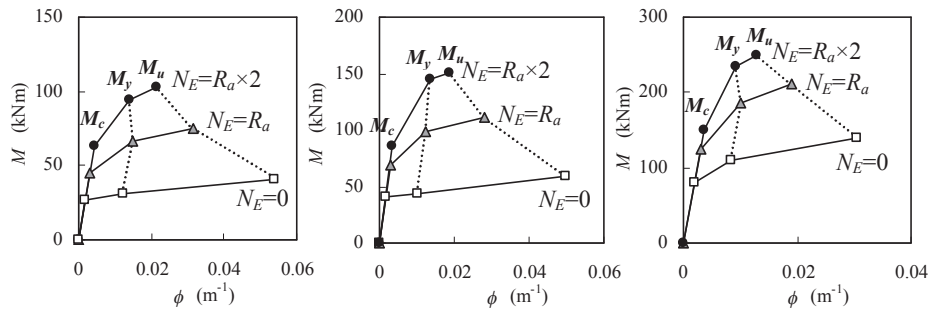

建物 $\mathrm{A} \cdot \mathrm{PC}$ 杭 $\phi 300$

建物 B·PC 杭 $\phi 350$ 建物 C·PHC 杭 (B 種) $) 400$

図 3 杭の $M$ - $\phi$ 関係

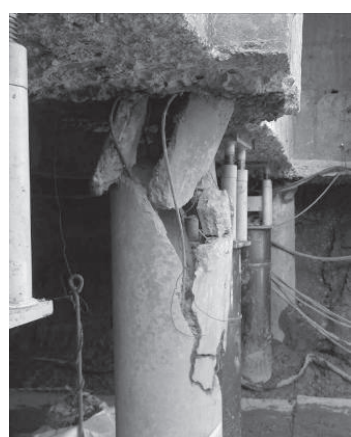

No.4 杭（杭頭大破）

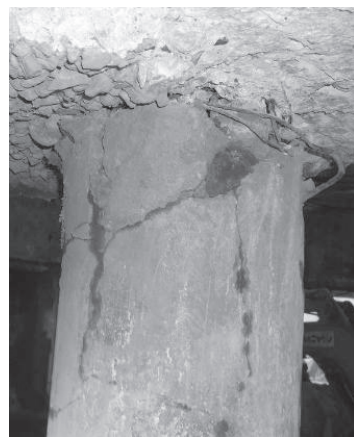

No.44 杭（杭頭中破）
写真 1 杭頭の破損状況

壁式プレキャスト構造で板状の整形な建物で, 同一径の既製コンク リート杭 $(\mathrm{PC}$ 杭・ $\phi 300 \mathrm{~mm})$ が軸力に応じて壁下に配置されている.

杭は打込み工法で施工され，杭長は不明であるが，本検討では杭 先端深さは GL-22.5m 一定とした。長期許容支持力 $R_{a}$ は $350 \mathrm{kN}$ で ある。なお，地震後の目視調査では杭頭のカットオフが行われた痕 跡が見られた。

本建物では，杭被害が一部に集中していること，被害を受けた杭 は隣接した杭でも破損位置が異なるのが特徵である ${ }^{177,18) .}$

杭の被害状況を図 5 に, 代表的被害を写真 1 に示す。ここで, 杭 頭の被害の判定としては, 目視により軸力が保持できないと判断さ れた場合は「大破」, 写真 1 の No.44 杭のようにある程度の軸力は保 持できると判断される場合は「中破」(杭頭の鋼線の露出はひび割れ 状況から施工時のカットオフの影響の可能性が高いと判断) , 軽微な ひび割れ程度の場合は「小破」とした．なお，敷地内に液状化は認 められなかった。

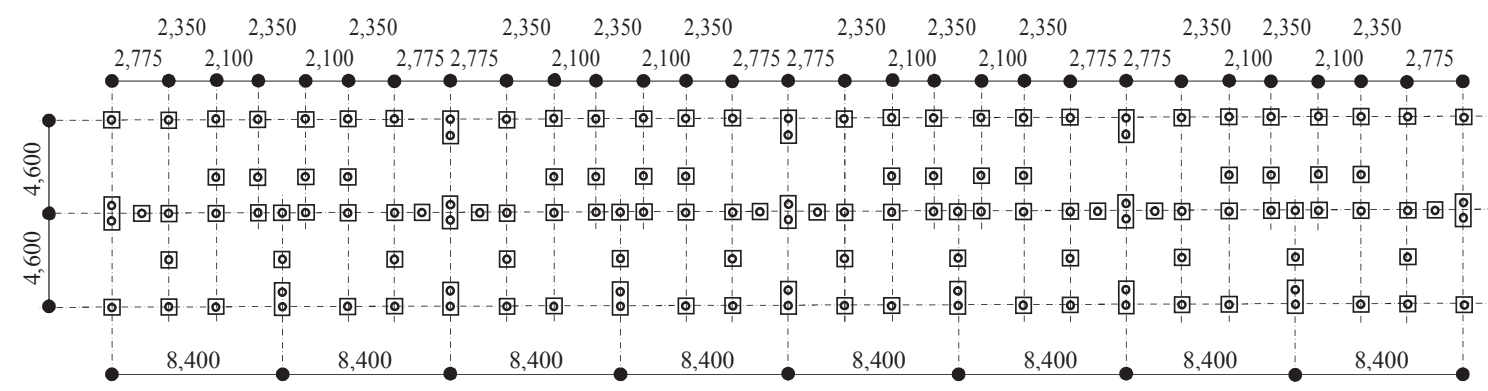

(単位:mm)

図 4 建物 $\mathrm{A}$ の杭伏図

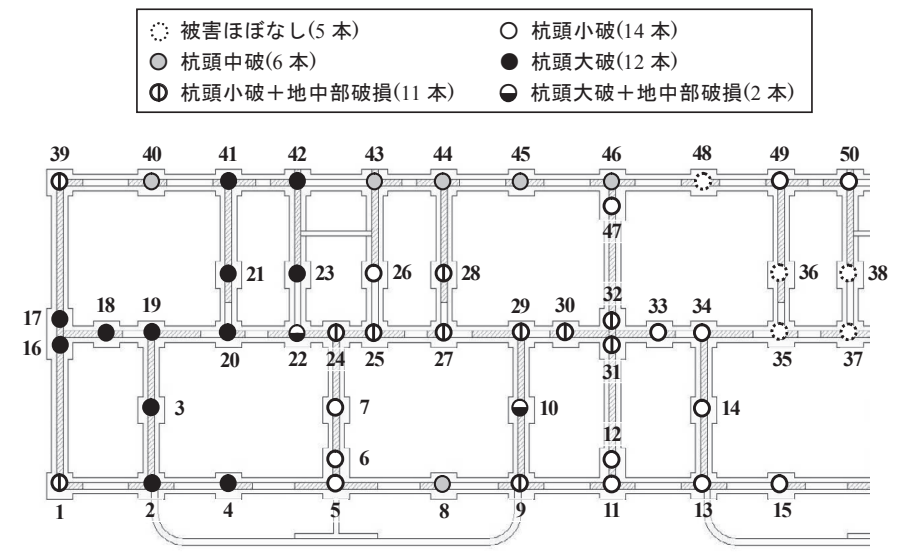

図 5 杭の被害状況

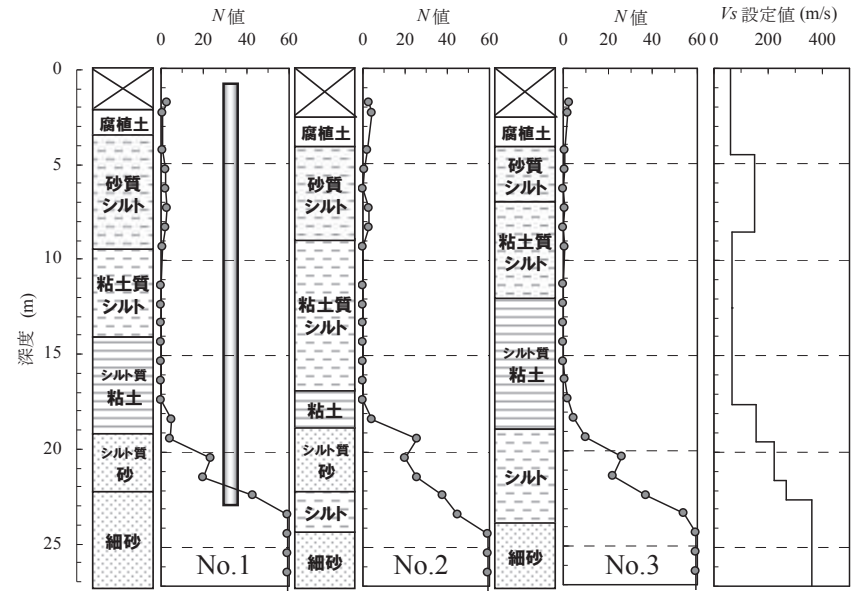

図 6 地盤調査結果および $V S$ の設定值 


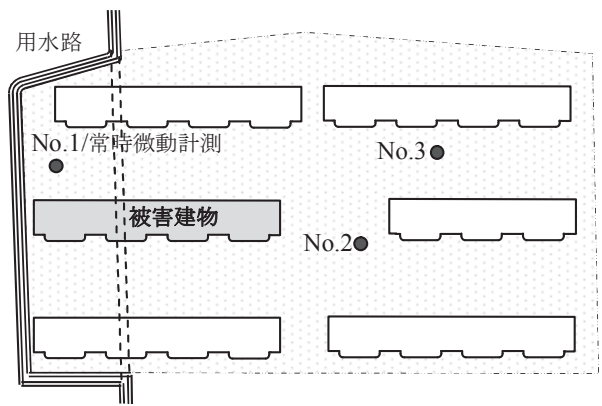

図 7 地盤調查位置

表 4 解析に用いた地盤定数（建物 $\mathrm{A}$ )

\begin{tabular}{cccccc}
\hline 層 & $\begin{array}{c}\text { 下端深度 } \\
\text { No. } \\
(\mathrm{m})\end{array}$ & $\begin{array}{c}V_{s} \\
(\mathrm{~m} / \mathrm{s})\end{array}$ & $\phi$ & $\begin{array}{c}c \\
\left(\mathrm{kN} / \mathrm{m}^{2}\right)\end{array}$ & $u$ \\
\hline 1 & 4.5 & $60^{*}$ & 0 & $20^{*}$ & 20 \\
2 & 8.5 & 150 & 0 & 20 & 20 \\
3 & 13.0 & 65 & 0 & 20 & 20 \\
4 & 17.5 & 65 & 0 & 20 & 20 \\
5 & 19.5 & 158 & 0 & 30 & 50 \\
6 & 21.5 & 222 & 32 & 0 & 150 \\
7 & 22.5 & 265 & 45 & 0 & 150 \\
\hline
\end{tabular}

地震後に実施された地盤調查の位置と得られた土質および $N$ 值分 布を図 6, 表 4 に示す. 地盤構成は表層から-20m 付近まで腐植土お よび軟弱でやや不均質な粘性土層が続いており, 敷地内では地層の 傾斜はほとんどない。せん断波速度 $V_{s}$ 值は, ボーリング No.1 の結 果から千葉市を中心とした地盤調査データに基づく提案式 ${ }^{12)}$ を用い て基づいて $N$ 值から設定し, GL-9〜-18m の $N$ 值 0 1 の粘性土層 については, 図 7 に示すボーリング地点の地表での常時微動計測を 行って同定した. 常時微動計測による $\mathrm{H} / \mathrm{V}$ スペクトルとそのフッテ イングを図 8 に, 同定した $V_{s}$ 值を表 4 にあわせて示す.

解析に用いる地盤定数を表 5 に示寸が， $P_{\max }$ 算定のための腐植土 層・粘性土層の粘着力 $c$ は沖積粘性土層の下限程度 ${ }^{19}$ の $20 \mathrm{kN} / \mathrm{m}^{2}$, その他の層の粘着力 $c$ および砂質土層の内部摩擦角 $\phi$ は $N$ 值から算 定 ${ }^{19), 20)}$ した. 非線形パラメータ $u$ は深度に応じて $u=20 \sim 150$ とした. これらから式(1), 式(2)を用いて設定した地盤ばねモデルを図 9 に示 す。 また, 本敷地では造成時に盛土と図 7 の破線で示すような水路 の付け替えもあり, 埋土層や腐植土層は自然堆積地盤に比べより不 均質である可能性が高いと考え, その影響を考慮するため, 表 5 に* で示寸層の $V_{s}$ 值および強度を $1 / 2$ と仮定した解析も行った.

また, 前述のように本建物では杭頭は無被害でも地中部で破損し た杭もあったが, 上部構造の壁や基礎ばりの位置と被害状況の関係 は明確でなく, 被害調査時には杭頭がパイルキャップにほとんど埋 め込まれていない杭も認められた。そこで，本検討では本建物の杭 頭回転剛性は固定〜ピン状態まで分布していたと仮定して, 杭頭固 定条件, および杭体弾性状態での杭頭モーメントの比 $\alpha$ 嘼定条件 に対して $0.5,0.05$ となるように調整した杭頭回転剛性を与えた解析 も行った.この比は弾性設計における杭頭固定度と同じ定義である.

応答解析のための入力地震動は建物から約 $3 \mathrm{~km}$ の距離にある国 土交通省「河川・道路等施設の地震計ネットワーク情報」の NS 方 向の観測波(最大加速度 NS : $2.33 \mathrm{~m} / \mathrm{s}^{2}, \mathrm{EW}: 1.95 \mathrm{~m} / \mathrm{s}^{2}, \mathrm{UD} \mathrm{NS}: 1.51 \mathrm{~m} / \mathrm{s}^{2}$ ) から，はぎ取りにより求めた基盤波を用いた。基盤面は杭先端の GL-22.5m とした。地盤の応答解析結果を図 10 に示寸.

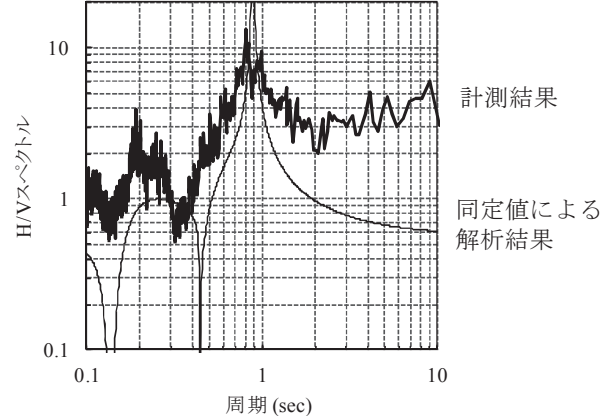

図 8 常時微動計測結果と同定結果
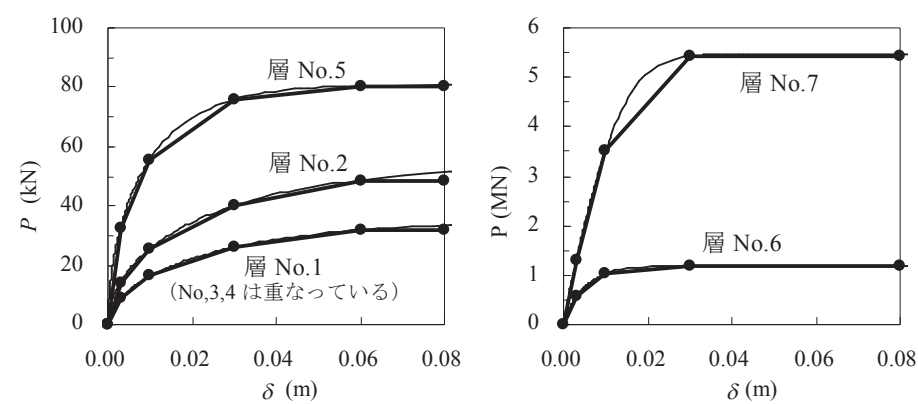

図 9 地盤ばねモデル

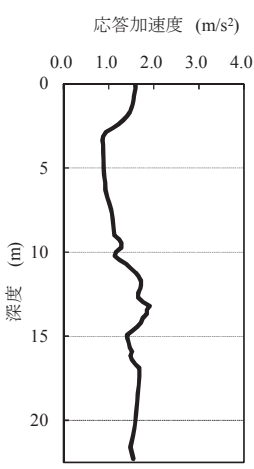

(1)応答加速度
地盤変形 $(\mathrm{m})$ 応答ひずみ $(\%)$

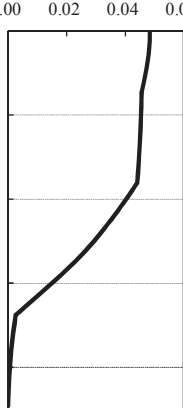

(2)地盤変形

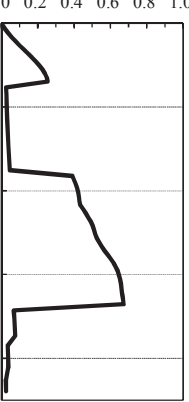

(3)応答ひずみ

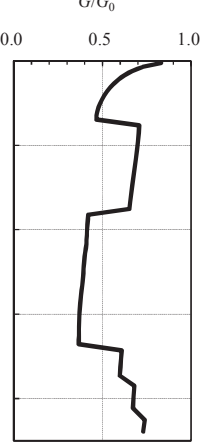

(4)せん断岡性低下率
地盤応答解析で得られた地表面応答加速度を用いて 3 . で示した 方法によって実施した建物の応答解析により得られた基䃈部分の応 答せん断力 $Q$ は, 総重量 $35,654 \mathrm{kN}$ に対し $9,763 \mathrm{kN}$, 杭 1 本あたり の平均杭頭水平力 $P$ は $70.7 \mathrm{kN}$ で，以下はすべての杭の負担力は同 一としてこの值を検討に用いる. 応力解析は, 以上から得られた地 盤変形 (杭先端からの相対変位) および杭 3 本分の杭頭水平力 $(3 \times P)$ を, 剛な基礎ばりで接続された $M-\phi$ 関係の異なる（負担軸力 : $N_{E}=0$, $\left.350 \mathrm{kN}\left(R_{\mathrm{a}}\right), 700 \mathrm{kN}\left(2 \times R_{\mathrm{a}}\right)\right) 3$ 本の杭に同時に，30 ステップの均等増分 で与えた。

図 11 に, 杭軸力 $N_{E}$ ごとに杭頭モーメントの比 $\alpha=1.0 \cdot 0.5 \cdot 0.05$ の 場合の曲げモーメント分布を示す.ここで, $N_{E}=0$ では $\alpha=1.0$ と 0.5 で杭頭が破壊に至っているが，その他のケースでは，一部にひび割 れ，降伏が見られるが，実際の被害と比べると発生モーメントはそ れほど大きくなっていない. 図 12 に外力として杭頭水平力のみを載 荷した場合の結果を示すが, $N_{E}=0$ での杭頭の破壊は杭頭水平力によ るもので，地盤変形の影響は大きくないことがわかる，そこで，図 13 に表層部の地盤ばねを $1 / 2$ とした場合の分布を示すが，杭頭回転 
剛性が低い場合は，非破壊試験の損傷の可能ありとされた深さより やや浅いが地中部あるいは杭頭と地中部の両方で降伏モーメントを 超える箇所があり，被害と対応している．さらに， $\alpha=0.5$ の結果は 杭頭が中破から小破程度の被害と対応していると考えられる.

また, 式(3)により求めたせん断強度 ${ }^{21} Q_{u}$, 解析から求められた杭 頭せん断力 $Q_{d}$ およびその比 $Q_{u} / Q_{d}$ を表 5 に示す. $Q_{u} / Q_{d}$ は $1.16 \sim 1.91$ となったが, 実際にはせん断破壊も考えられる被害も見られており,

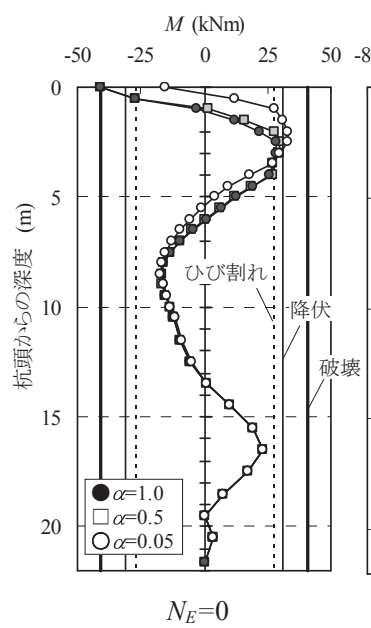

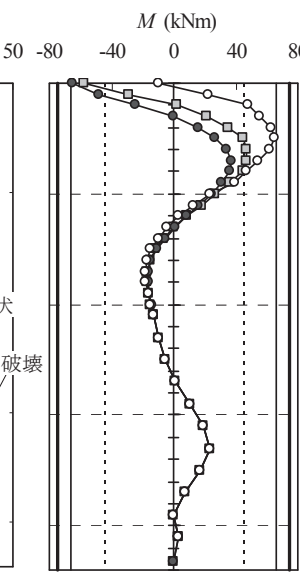

$N_{E}=R_{a}$
$M(\mathrm{kNm})$

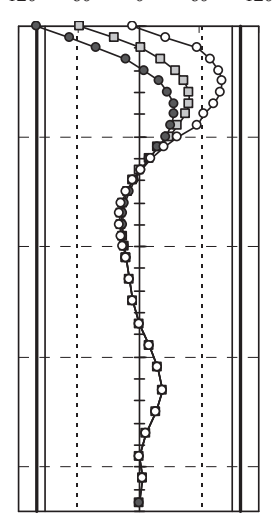

$N_{E}=R_{a} \times 2$
図 11 杭の曲げモーメント分布 $(\alpha=1.0,0.5,0.05)$

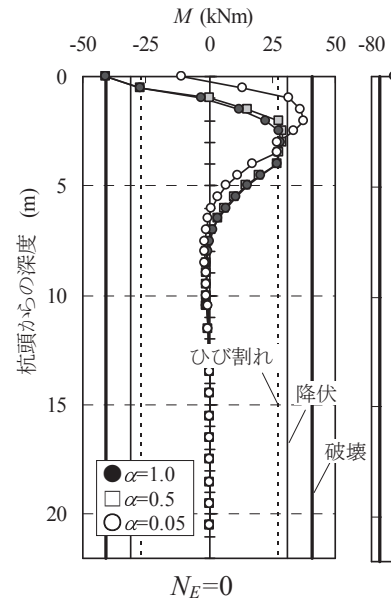
$M(\mathrm{kNm})$ $M(\mathrm{kNm})$
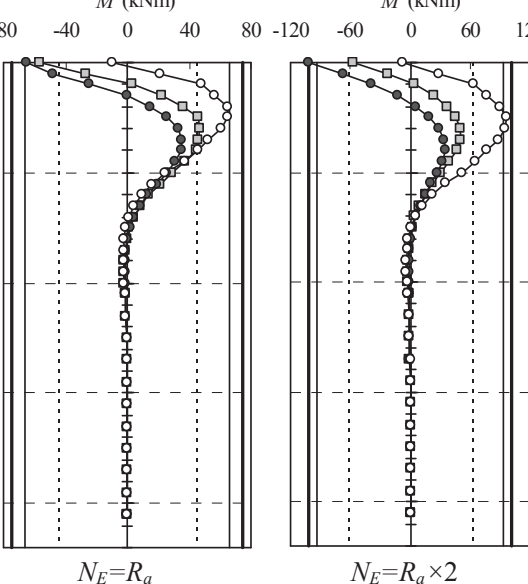

図 12 杭頭水平力のみによる杭の曲げモーメント分布

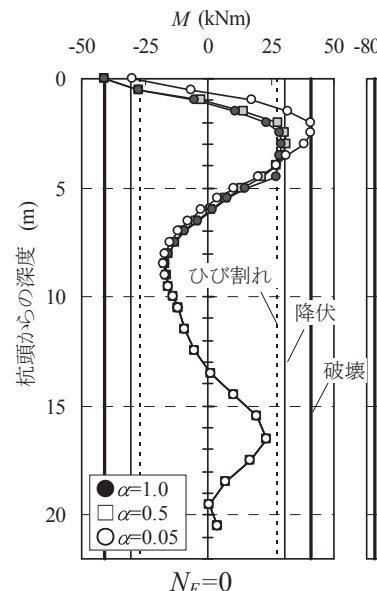
$M(\mathrm{kNm})$

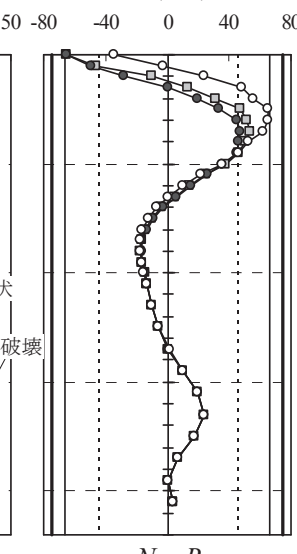

$N_{E}=R_{a}$ $M(\mathrm{kNm})$ $\begin{array}{lllll}-120 & -60 & 0 & 60 & 120\end{array}$

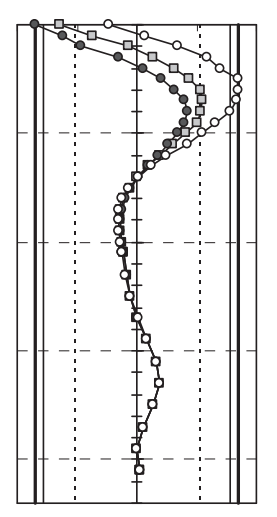

$N_{E}=R_{a} \times 2$

図 13 表層地盤の地盤ばね $1 / 2$ の時の杭の曲げモーメント分布

計算誤差や施工時のカットオフの影響などを考えると, 安全余裕が 十分でなかった可能性もある。

$$
Q_{u}=\frac{2 t I}{S_{0}} \cdot \frac{1}{2} \sqrt{\left(\sigma_{g}+2 \phi \sigma_{t}\right)^{2}-\sigma_{g}^{2}}
$$

記号 $t$ : 肉厚 $(\mathrm{mm}), S_{0}$ : 断面 1 次モーメント $\left(\mathrm{mm}^{3}\right), I$ : 断面 2 次モーメント $\left(\mathrm{mm}^{4}\right), \sigma_{g}$ :軸方向応力度 $=\sigma_{e}+N_{E} / A, A$ : 杭断面積 $\left(\mathrm{mm}^{2}\right), \sigma_{e}$ : 有 効プレストレス $\left(\mathrm{N} / \mathrm{mm}^{2}\right), N_{E}$ : 軸力 $(\mathrm{N}) ， \sigma_{t}$ : コンクリート引張強度 $\left(=0.07 F=3.5 \mathrm{~N} / \mathrm{mm}^{2}\right)^{22)}, F$ : コンクリート圧縮強度 $\left(=50 \mathrm{~N} / \mathrm{mm}^{2}\right)^{22)}$, $\phi$ :せん断破壊時の斜張応力度とコンクリートの引張強度の比 (PHC 杭に準じて 0.5 とした) ${ }^{23)}$

\begin{tabular}{c|c|c|c|c} 
表 5 せん断耐力 $Q_{u}$ と解析で求められたせん断力 $Q_{d}$ \\
\hline$N_{E}$ & $Q_{u}(\mathrm{kN})$ & $\alpha$ & $Q_{d}(\mathrm{kN})$ & $Q_{u} / Q_{d}$ \\
\hline & & 1.0 & 59.7 & 1.25 \\
0 & \multirow{3}{*}{74.7} & 0.5 & 64.4 & 1.16 \\
& & 0.05 & 58.3 & 1.28 \\
\hline & & 1.0 & 73.4 & 1.55 \\
350 & \multirow{2}{*}{113.7} & 0.5 & 73.6 & 1.54 \\
$\left(R_{a}\right)$ & & 0.05 & 69.7 & 1.63 \\
\hline & & 1.0 & 80.3 & 1.77 \\
700 & \multirow{2}{*}{142.4} & 0.5 & 74.7 & 1.91 \\
$\left(2 R_{a}\right)$ & & 0.05 & 76.3 & 1.87 \\
\hline
\end{tabular}

以上から, 本建物の被害は, 被害の大きい部分で特に表層地盤が 軟弱な部分があり，杭頭回転剛性が高い杭では杭頭の破壊が生じ， 杭頭回転剛性が低い杭では地中部でも破壊したために, 被害範囲全 体が支持性能を失って傾斜が生じたと考えられる。

なお，杭頭 $-7 \mathrm{~m}$ 付近でもクラックの可能性があり，本検討でも GL-4〜 - 8.5m の砂質シルト層下端で地盤変形によりモーメントが増 大寸る結果が得られたが，ひび割れモーメント以下であり，再現の ためには地盤調査の追加等による地盤ばねの精度向上が必要である と考えられる.

\section{5. 建物 B の検討}

建物 B の杭伏図を図 14 に示す. 上部構造は地上 5 階地下なしの 耐震壁付きラーメン構造の整形な建物で，同一径の既製コンクリー 卜杭 $(\mathrm{PC}$ 杭・ $\phi 350 \mathrm{~mm})$ が柱下に $2 \sim 6$ 本配置されている. 杭の施 工方法は打込夕杭で, 設計図書では杭先端深さは GL-20m が 74 本・ GL- $30 \mathrm{~m}$ が 23 本・計 97 本となっている. 長期許容支持力 $R_{a}$ は $450 \mathrm{kN}$ 程度と推定される。

建物近くで地震後に実施された 2 か所の地盤調査の位置と得られ た土質および $N$ 值分布および設定した $V_{s}$ 值を図 15 に示寸.ここで, $V_{s}$ 值は太田・後藤による関係式 ${ }^{13}$ による計算值を参考に, 図 16 に 示寸対象建物から約 $0.4 \mathrm{~km}$ の距離にある防災科学技術研究所強震観 測網(K-NET)観測点の $V_{s}$ 值に基づいて設定した.なお, 図 16 の GL-5 〜-10m にある砂碩層は建物 B に隣接する建物では確認されており, これら 2 地点は同じ地層と判断した。 また, 東日本大震災で近隣で は液状化による噴砂が見られたが, 本敷地内では認められなかった。 ここで, No.1,No.2 のボーリング結果は GL-20m までの地盤構成 （砂質土と粘性土の互層）は類似しているが，GL-20m 付近から出 現する砂碟層の厚さの違いにより杭の支持地盤も異なっている. そ こで，地盤の応答解析もボーリング孔ごとに行うものとして，地盤 ばねもそれぞれ設定した。解析に用いた地盤定数を表 6 に示す. 


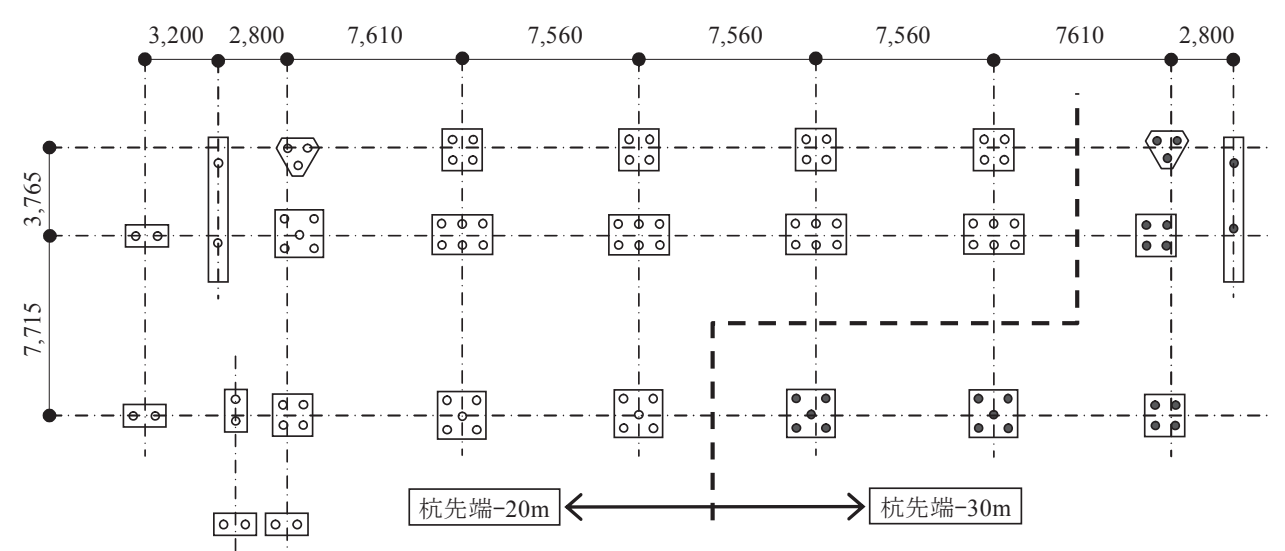

(単位: $\mathrm{mm}$ )

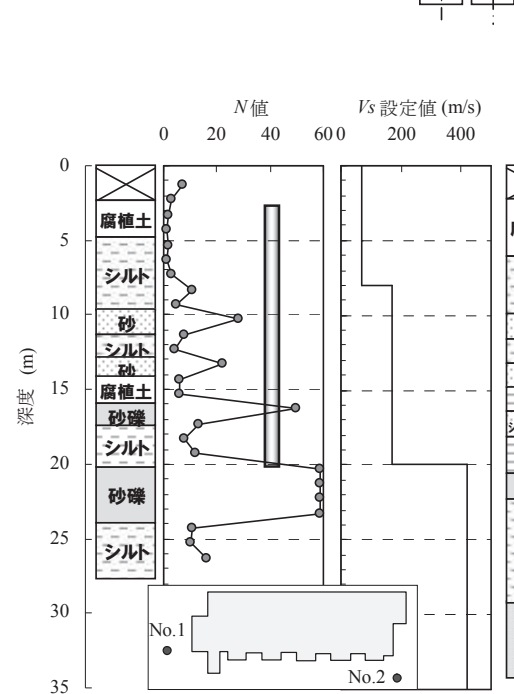

No.1

図 15 地般調查結果および $V$ の計算值
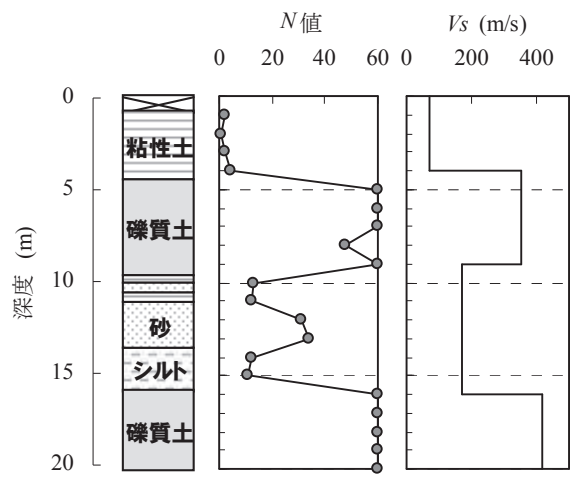

図 16 近隣の K-NET 観測点の速度構造

表 6 解析に用いた地盤定数（建物 B)

\begin{tabular}{lccccc}
\multicolumn{2}{l}{ No.1 } \\
\hline $\begin{array}{c}\text { No層端 } \\
\text { No. }\end{array}$ & $\begin{array}{c}V_{s} \\
(\mathrm{~m})\end{array}$ \\
$(\mathrm{m} / \mathrm{s})$ & $\phi$ & $\begin{array}{c}c \\
\left(\mathrm{kN} / \mathrm{m}^{2}\right)\end{array}$ & $u$ \\
\hline 1 & 2.0 & $70^{*}$ & 0 & $31^{*}$ & 20 \\
2 & 5.0 & $70^{*}$ & 0 & $20^{*}$ & 20 \\
3 & 8.0 & 70 & 0 & 20 & 20 \\
4 & 12.0 & 170 & 0 & 81 & 50 \\
5 & 16.0 & 170 & 0 & 59 & 100 \\
6 & 20.0 & 170 & 0 & 69 & 150 \\
\hline
\end{tabular}

\begin{tabular}{cccccc}
\multicolumn{3}{l}{ No.2 } \\
$\begin{array}{c}\text { 層 } \\
\text { No. }\end{array}$ & $\begin{array}{c}\text { 端度 } \\
(\mathrm{m})\end{array}$ & $\begin{array}{c}V_{s} \\
(\mathrm{~m} / \mathrm{s})\end{array}$ & $\phi$ & $\begin{array}{c}c \\
\left(\mathrm{kN} / \mathrm{m}^{2}\right)\end{array}$ & $u$ \\
\hline 1 & 2.0 & $70^{*}$ & 0 & $47^{*}$ & 20 \\
2 & 6.0 & $70^{*}$ & 0 & $20^{*}$ & 20 \\
3 & 8.0 & 70 & 0 & 23 & 20 \\
4 & 13.0 & 170 & 0 & 73 & 50 \\
5 & 18.0 & 170 & 0 & 91 & 100 \\
6 & 23.0 & 170 & 0 & 70 & 100 \\
7 & 30.0 & 170 & 0 & 81 & 150 \\
\hline
\end{tabular}

図 14 建物 B の杭伏図
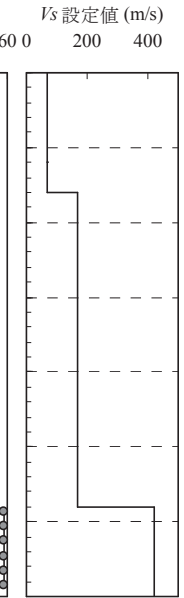

2

\section{值}

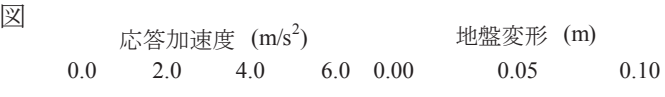

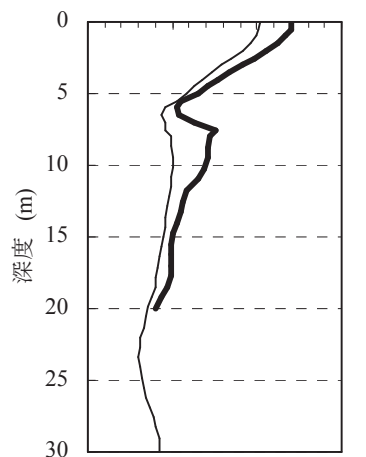

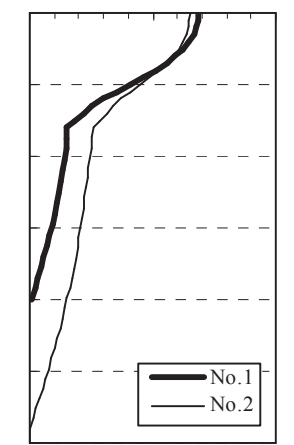

図 17 地盤応答加速度・地盤変位の分布
以下の検討方法は建物 $\mathrm{A}$ と同様であるが, 本建物の杭の被害とし ては，杭頭コンクリートが圧潰し PC 鋼線が座屈したが，抜け出し は見られなかったことから杭頭部の固定度は確保されていたと判断 し, 解析は $\alpha=1.0$ のケースのみを実施した.

入力地震動は近隣の K-NET 観測点（最大加速度 NS: $4.51 \mathrm{~m} / \mathrm{s}^{2}$, $\mathrm{EW}: 4.21 \mathrm{~m} / \mathrm{s}^{2}, \mathrm{UD}: 1.28 \mathrm{~m} / \mathrm{s}^{2}$ )の NS 方向の記録を用いた. 応答加速度. 地盤変形の分布を図 17 に示寸. 建物の応答解析も 2 種類の地盤条件 で実施したが, 杭頭水平力は基礎部分の応答せん断力 $Q$ のうちの大 きい方の $13,665 \mathrm{kN}$ とした. なお，この地盤条件で算定した杭長 $20 \mathrm{~m}$ と $30 \mathrm{~m}$ の杭の水平剛性の比は, 1:0.97 程度であり, 杭長・地盤の違 いは無視して水平力を均等に負担するものとした,

応力解析は建物 $\mathrm{A}$ と同じであるが, 杭長ごとに別のモデルとした 負担軸力は $N_{E}=0,450 \mathrm{kN}\left(R_{a}\right), 900 \mathrm{kN}\left(2 \times R_{a}\right)$ である.

図 18 に，杭軸力 $N_{E}$ ごとにそれぞれの杭長の曲げモーメント分布 を示す，す心゙ての杭頭部で破壊に至っており，そのために建物が支 持できなくなり建物の傾斜につながったと考えられる，ただし，本 建物で見られた $300 \mathrm{~mm}$ を超える不同沈下が生じるためには地中部 の破壞の可能性も高いが, 地中応力は降伏もしくはひび割れ程度で ある.また，杭頭水平力のみでも建物 $\mathrm{A}$ と同様に杭頭破壊は生じる が，地中部の応力はさらに小さい.

そこで, 本建物も建物 $\mathrm{A}$ と同様に腐植土層の上に盛土して造成さ れていることから，その不均質性を想定して地盤ばねを $1 / 2$ とした 場合の解析も実施した. 図 19 に結果を示寸が杭長が短い杭は地中部 GL-4m 付近で破壊に至っており, 表層地盤の剛性がより低い部分で は杭頭と地中部が合わせて破損したことも考えられる.

以上から, 今回の検討によれば, 本建物の被害の状況をほぼ再現 
していると考えられるが, 地震動の評価や今回考慮しなかったロッ キング変形に対する支持地盤の傾斜の影響等は考慮できておらず, より厳密な評価のためには, これらに着目した検討も必要である.

\section{6. 建物 C の検討結果}

建物 C の杭伏図を図 20 に示す。 上部構造は地上 3 階地下なしの 耐震壁付きラーメン構造のほぼ整形で, 同一径 $(\phi 400 \mathrm{~mm})$ の $\mathrm{PHC}$ 杭（B 種）が柱下に $1 \sim 6$ 本配置されている. 杭の施工方法はオーガ 一併用最終打撃工法で, 杭先端 $2 \mathrm{~m}$ 分は打撃貫入している. 設計図 書によれば杭長 $13 \mathrm{~m}$ が 48 本・14m が 69 本・16m が 36 本（それぞ
れ $+1 \mathrm{~m}$ 試験杭 2 本を含む) 計 153 本である. 長期許容支持力 $R_{a}$ は $600 \mathrm{kN}$ で，短期許容応力度設計による水平力に対する検討も行われ ている，東日本大地震時には液状化は認められなかった。

本建物では設計時に 3 か所の地盤調查が行われている. 図 21 に示 すように, GL-13m〜-15m までは比較的硬質の砂碩とシルトの互層 で層厚や層序はばらついており, 杭の支持層となる砂質シルト岩層 は全体に傾斜している. 杭長はこの傾斜に対応していることから， 本建物でも地盤の応答解析や地盤ば初の設定もボーリング孔ごとに 行った．解析に用いた地盤定数を表 7 に示寸. $V_{s}$ 值は建物 B と同様 に K-NET 観測点の速度構造に基づいている。

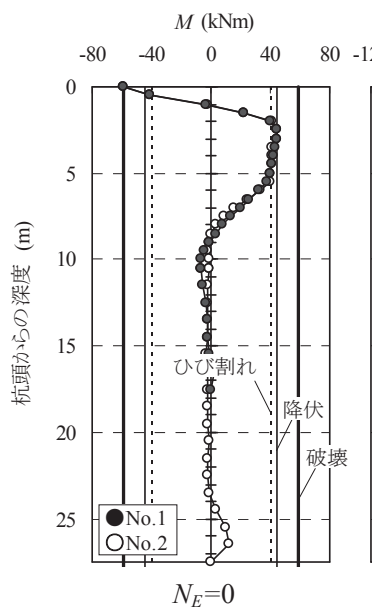
$M(\mathrm{kNm})$ $M(\mathrm{kNm})$
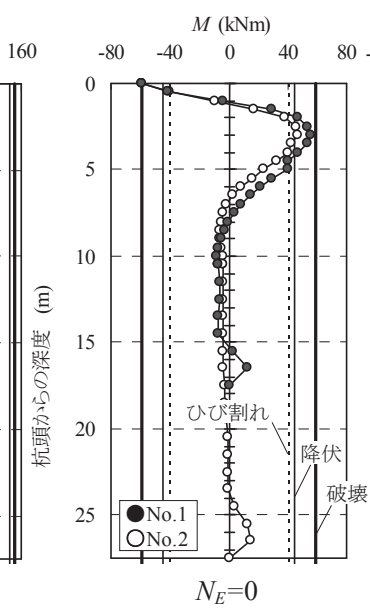
$M(\mathrm{kNm})$

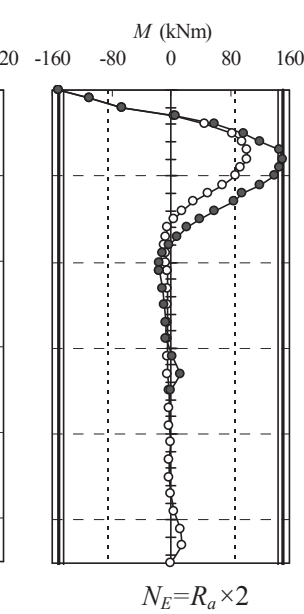

図 18 杭の曲げモーメント分布
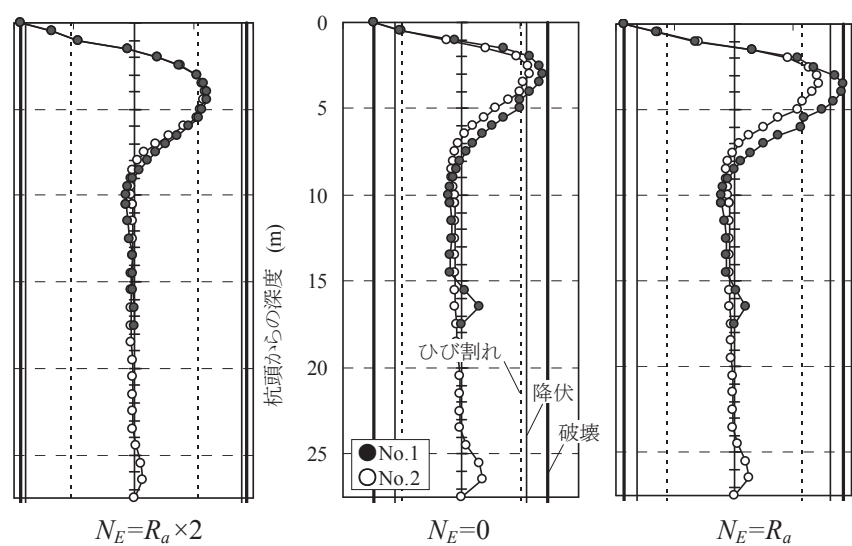

図 19 表層地盤の地盤ばね $1 / 2$ の時の杭の曲げモーメント分布

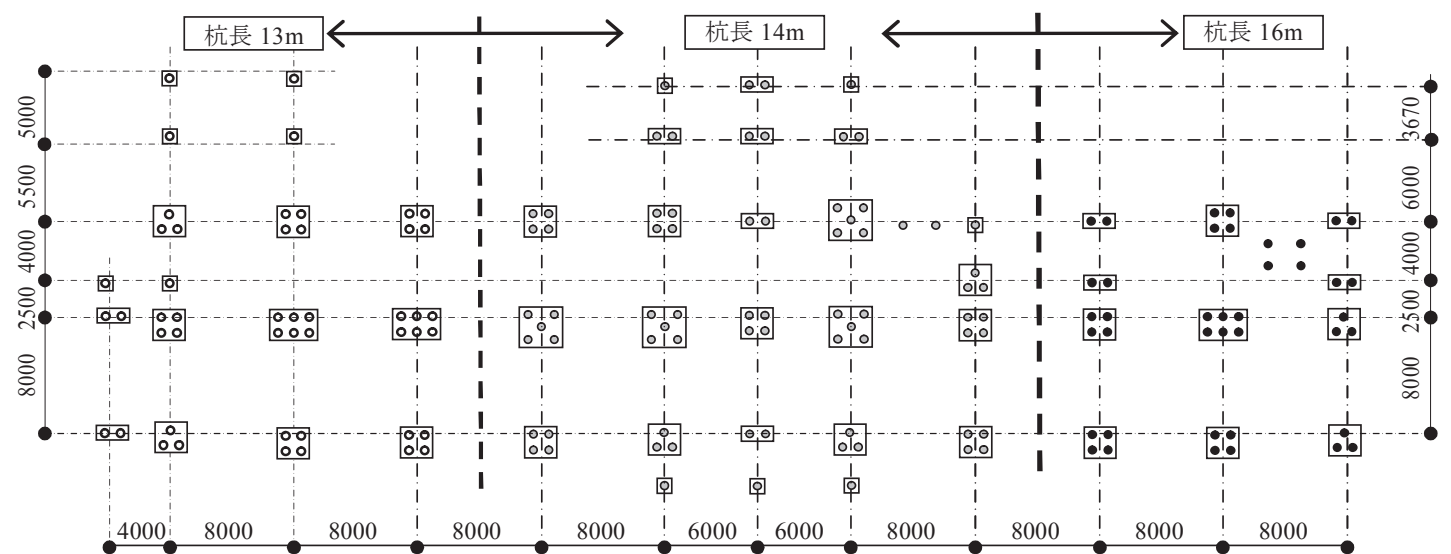

図 20 建物 $\mathrm{C}$ の杭伏図

(単位: $\mathrm{mm}$ )
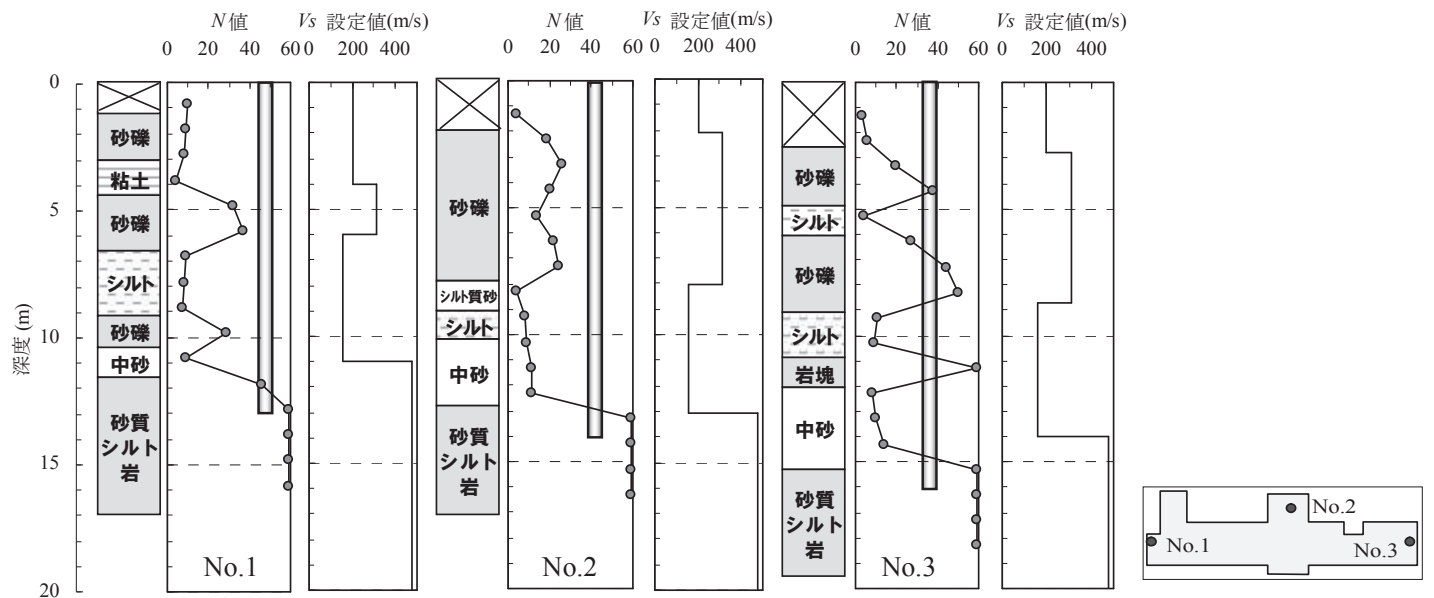

図 21 地盤調查結果および $V_{s}$ の設定值（建物 $\mathrm{C}$ ) 
表 7 解析に用いた地盤定数 (建物 C)

\begin{tabular}{|c|c|c|c|c|c|c|}
\hline & 層No. & 下端深度 $(\mathrm{m}$ & $V_{s}(\mathrm{~m} / \mathrm{s})$ & $\phi$ & $c\left(\mathrm{kN} / \mathrm{m}^{2}\right)$ & $u$ \\
\hline \multirow[t]{6}{*}{ No.1 } & 1 & 2.0 & 200 & 0 & 59 & 20 \\
\hline & 2 & 4.0 & 200 & 0 & 38 & 20 \\
\hline & 3 & 6.0 & 310 & 41 & 0 & 50 \\
\hline & 4 & 8.5 & 160 & 28 & 0 & 50 \\
\hline & 5 & 11.0 & 160 & 32 & 0 & 100 \\
\hline & 6 & 13.0 & 480 & 0 & 313 & 150 \\
\hline \multirow[t]{7}{*}{ No.2 } & 1 & 1.85 & 200 & 0 & 25 & 20 \\
\hline & 2 & 4.0 & 310 & 36 & 0 & 50 \\
\hline & 3 & 6.0 & 310 & 33 & 0 & 50 \\
\hline & 4 & 8.1 & 310 & 36 & 0 & 50 \\
\hline & 5 & 10.6 & 160 & 27 & 0 & 50 \\
\hline & 6 & 13.1 & 160 & 29 & 0 & 100 \\
\hline & 7 & 14.0 & 480 & 0 & 313 & 150 \\
\hline \multirow[t]{7}{*}{ No.3 } & 1 & 2.4 & 200 & 0 & 28 & 20 \\
\hline & 2 & 5.7 & 310 & 39 & 0 & 50 \\
\hline & 3 & 6.7 & 310 & 0 & 25 & 50 \\
\hline & 4 & 8.7 & 310 & 43 & 0 & 50 \\
\hline & 5 & 11.4 & 160 & 35 & 0 & 50 \\
\hline & 6 & 14.0 & 160 & 30 & 0 & 100 \\
\hline & 7 & 16.0 & 480 & 0 & 313 & 150 \\
\hline \multicolumn{4}{|c|}{ 応答加速度 $\left(\mathrm{m} / \mathrm{s}^{2}\right)$} & \multicolumn{3}{|c|}{ 地盤変形 (m) } \\
\hline 0.0 & 2.0 & 6.0 & $3.0 \quad 0.00$ & 0.01 & 0.02 & 0.03 \\
\hline
\end{tabular}
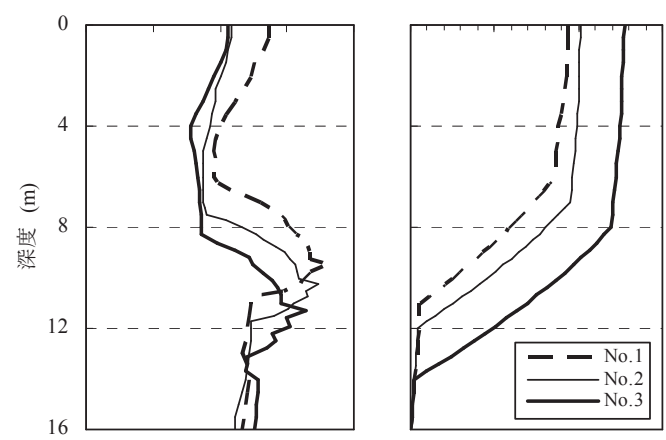

図 22 地盤応答加速度・地盤変位の分布

以下の検討方法は建物 $\mathrm{A}, \mathrm{B}$ と同じで, 応力解析は杭長ごとに負 担軸力 $\left(N_{E}=0,600 \mathrm{kN}\left(R_{a}\right), 1200 \mathrm{~N}\left(2 \times R_{a}\right)\right)$ の異なる 3 本の杭からなるモ デルを用いた．杭頭部は被害のあった杭では固定度ある程度確保さ れていたと考えられるが, 傾斜部分以外では杭頭の被害はなく, 固 定度の影響も考えられることから $\alpha=1.0 ， 0.5$ の解析を実施した。

入力地震動は対象建物から約 $4.4 \mathrm{~km} の \mathrm{~K}-\mathrm{NET}$ 観測点（最大加速 度 $\mathrm{NS}: 6.19 \mathrm{~m} / \mathrm{s}^{2}, \quad E W: 5.52 \mathrm{~m} / \mathrm{s}^{2}, \quad U D: 3.31 \mathrm{~m} / \mathrm{s}^{2}$ ) の記録の NS 成分を用 いた。 応答加速度, 地盤変形の分布を図 22 に示寸.

杭頭水平力の算定では, 杭長や地盤条件（特に表層地盤（埋土） の厚さ）の違いを考慮するため, 1 階の重心位置および杭の水平剛 性・本数・配置から上部構造と同様な方法で偏心の影響を考慮した. 杭の水平剛性の比は $1.0(13 \mathrm{~m}): 0.88(14 \mathrm{~m}): 0.78(16 \mathrm{~m})$ で, 基礎部分の応 答せん断力 $Q$ は $28,542 \mathrm{kN}$ に対して, 偏心を考慮した負担力は $178.8 \mathrm{kN} /$ 本, $188.3 \mathrm{kN} /$ 本, $193.5 \mathrm{kN} /$ 本となった.

図 23 に $\alpha=1.0$, 図 24 に $\alpha=0.5$ での曲げモーメント分布を示寸. こ こで， $\alpha=1.0$ の場合はいずれも杭頭部は破壊に至っているが，これ はほとんど杭頭水平力によるものである. 地中部は一 $-3 \mathrm{~m}$ 付近に加 え, 杭の先端より $1 \mathrm{~m}$ 程度上の部分でひび割れモーメントを超えて おり，地中部の破損が支持力低下につながった可能性がある.

$\alpha=0.5$ では, 杭長 $13 \mathrm{~m}$ の杭では杭頭はひび割れモーメント前後, 被害の見られた側の杭長 $16 \mathrm{~m}$ の杭では杭頭部および地中部で降伏 を超え, 被害状況に近い結果となり, 杭頭固定条件の影響もあると
考えられる.ただし, 杭頭固定条件一の違いがあるとした場合, そ れが施工時の問題のような不確定な要因によるのか，基礎ばりの拘 束や 1 階の耐震壁等の上部構造の影響によるものなのかは今後精査 が必要である.

\section{7. 設計手法の確立のための課題}

以上の検討は, 特に地盤や杭体について仮定条件を設けおり, 精 度を確保した上で設計法としての適用性が高いと思われる設計手 法を確立するめには, 以下のような課題がある.

(1)杭体の強度・変形特性の評価

・図 3 では破壊モーメント後も変形性能を維持する解析モデルとな っているが．既製コンクリート杭では破壊後は急激な剛性低下が 考えられ. その定量的な評価と解析上の扱いは検討が必要である.

・多数の杭がある場合のグルーピング方法, 群杭効果の評価 (2)地盤の評価

・上部構造（基礎ばりや 1 階の耐震壁等）による杭頭拘束の効果

・支持層の傾斜による地盤および建物の応答性状の厳密な評価

・ $V_{s}$ 值が直接得られていない場合の設定方法の違いによる影響

(3)外力（設計用荷重）の評価

・上部構造の応答に伴う変動軸力およびロッキング変形の評価

・根入れ部分の影響の評価

ただし，外力の正確な評価のためには，上部構造を含む一体で立 体モデル化して動的解析が必要であるが，汎用性があるとはいえな い，設計手法としての適用拡大をはかるためには，本検討のような 被害との比較や高度な解析との比較を通じて, 本論文で提案したよ うな解析手法の精度の向上をはかることが望ましいと考える.

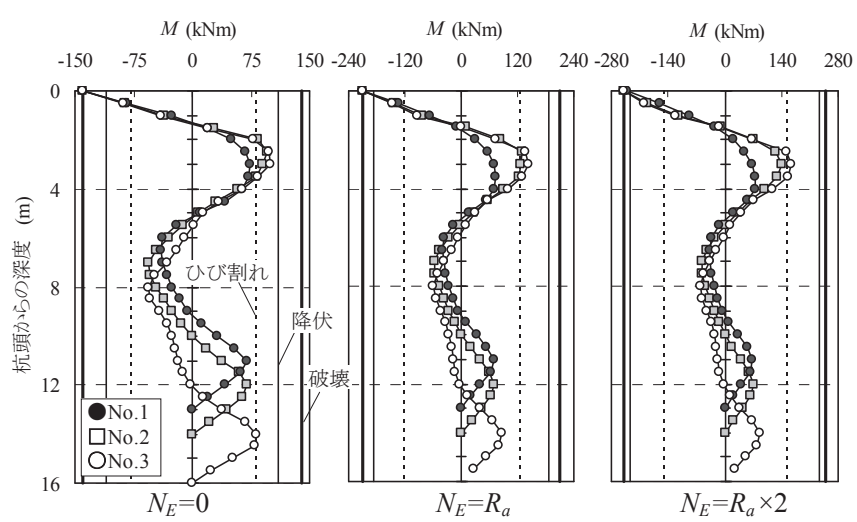

図 23 杭の曲げモーメント分布 $(\alpha=1.0)$

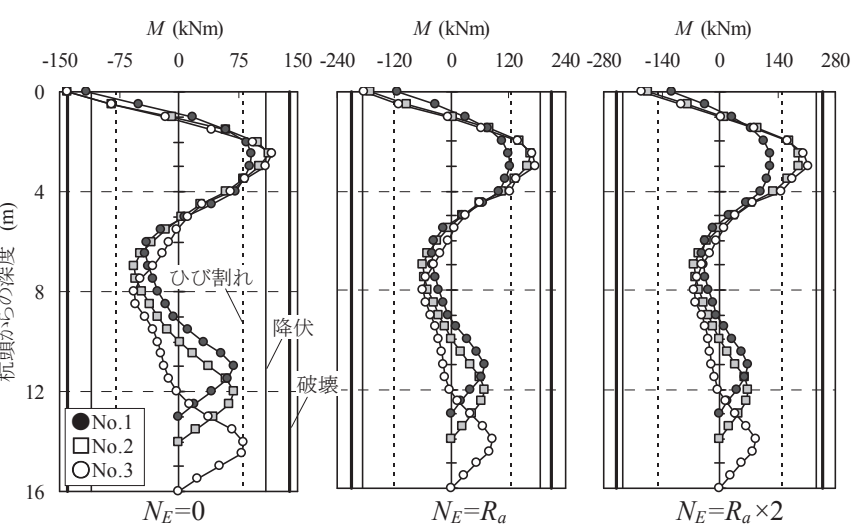

図 24 杭の曲げモーメント分布 $(\alpha=0.5)$ 


\section{8. 結論}

1) 大地震時の耐震性評価のための設計法としての適用性が高いと 思われる解析手法を採用し, 東日本大震災において破損した杭基 礎の被害について検証した結果，設定した手法により被害をほぼ 説明可能であることを確認した。

2) 今回検討した建物では, 杭頭部は杭頭水平力のみでも破壊に至る 検討結果であり，杭頭水平力が杭体の損傷の主要因となっている が, 表層部の地盤の剛性が低く地盤変形が大きくなることが地中 部の破壊に寄与している可能性がある.

3) 建物 A で, 一部の杭のみが破損し長手方向に傾斜した要因は, 表層の埋土や腐食土層の地盤の平面的な不均質性の影響，つまり 被害のあった側では, 造成時の地盤条件の違いなどで表層部の地 盤の剛性が他よりも低いことによると考えられる。また，杭の破 損位置がそれぞれ異なるのは, 杭の配置や施工の影響による杭頭 回転剛性の違いによると考えられる.

4) 建物 A では, 解析で得られたせん断力はせん断強度よりやや小 さい值であったが，実際の被害ではせん断破壊と見られる杭もあ り, 地盤や杭体のばらつき, 解析の誤差を考えると, せん断強度 に愛寸る安全余裕が小さかったことが考えられる.

5) 建物 Cでの長手方向の傾斜をもたらした杭の被害の違いは, 杭長 や地盤の違いに, 杭頭固定度の影響が加わったものと考えられる. また, 支持地盤が比較的硬質であるために, 地盤変形により杭先 端付近でもひび割れモーメントを超えていた可能性もある.

\section{謝辞}

本検討に用いた建物の被害調査は，平成 24 年度国土交通省建築 基準整備促進事業「基礎ぐいの地震に対する安全対策の検討」とし て実施した独立行政法人建築研究所との共同研究の成果に基づくも のである．地盤および建物の地震応答解析は戸田建設(株)成田修英 氏の, 建物 A の常時微動測定は千葉大学関口徹助教, 学部生・西本 昌氏の協力による。関係各位に深謝する.

\section{参考文献}

1) 杉村義広・大岡弘，1978 年宮城県沖地震による既製コンクリート杭の被 害調查報告，建築研究報告 No.31, 1981

2) 建築基礎における液状化・側方流動対策検討委員会（BTL 委員会），兵 庫県南部地震における液状化・側方流動に関する研究, 建築研究報告 No.138，2000

3) 日本建築学会近畿支部, 兵庫県南部地震による建築基礎の被害事例調查報 告書, 1996

4) 日本建築学会, 2011 年東北地方太平洋沖地震災害調査速報, 2011

5) 日本建築学会, 基礎構造の地震被害と耐震設計, 2012 年度日本建築学会 大会（東海）構造部門（基礎構造）パネルディスカッション資料， 2012

6) Fujii, S., Isemoto, N., Satou, Y., Kaneko, O., Funahara, H., Arai, T. and Tokimatsu,K., Investigation and analysis of a pile foundation damaged by liquefaction during the 1995 Hyogoken-nambu earthquake, Special issue of Soils and Foundations, pp.179-192,1998.9

7) 古山田耕司, 宮本裕司, 福田孝晴 : 2003 年十勝沖地震における杭の実被 害調査とその解析的検討, 日本建築学会構造系論文集, 第 589 号, pp.97-104, 2005.3

8) 山添正稔，迫田丈志，三辻和弥，前田匡樹：2011 年東北地方太平洋沖地 震により被災した RC 造校舎の被害と沈下要因の検討（その 2 地震応答 解析），日本建築学会大会学術講演梗概集 構造 I, pp.21-24, 2012

9) 2007 年度版建築物の構造関係技術基準解説書, p.262, 2007

10) 日本建築学会：建築耐震設計における保有耐力と変形性能 基礎構造, pp.127-209, 1990

11）金子治, 中井正一, 二木幹夫 : 建築基礎構造の耐震診断手法の提案と適
用例, 第 47 回地盤工学研究発表会, pp.1111-1112，2012

12) 永田葉子, 中井正一, 関口徹 : 千葉市を中心とした千葉県北西部におけ る土質別 $\mathrm{S}$ 波速度の検討，日本建築学会技術報告集，第 14 巻第 28 号, pp.429-432，2008.10

13) 太田裕，後藤典俊：S 波速度を他の土質的諸指標から推定する試み，物理 探鉱, Vol.29, No.4, pp.31-41, 1976

14) 安田進, 山口勇 : 種々の不擋乱土における動的変形特性第 20 回土質工学 研究発表会, 539-542, 1985

15) 間瀬辰也, 中井正一: 単杭の杭周地盤ばねの評価法に関する検討, 日本 建築学会構造系論文集，第 680 号，pp.1527-1535，2012.10

16）岸田英明, 中井正一: 地盤反力一変位関係の非線形性, 土と基礎, Vol.25, No.8, pp.21-28, 1977

17）金子治，中井正一，成田修英：東日本大震災において被災した杭基礎の 被害メカニズムの検討, 日本建築学会大会学術講演梗概集 構造 I, pp.547-548, 2013

18）田口智也，金子治：2011 年東日本大震災において杭基礎が被災した東京 湾岸部に建つ集合住宅，日本建築学会大会学術講演梗概集＼cjkstart構造 I， pp.477-478, 2012

19) 地盤工学会 : 地盤調査の方法とその解説, p.267, 2004

20) 日本建築学会 : 建築基礎構造設計指針, p.114，2001

21) 前掲 10), p.142, 1990

22）コンクリートポール・パイル協会 : PC パイルハンドブック，p.61，1970

23) コンクリートパイル建設技術協会 : 既製コンクリート杭一基礎構造設計

マニュアル, p.58, 2009

（2013年 6 月 10 日原稿受理，2013年10月 3 日採用決定） 